\title{
Carcass and meat quality in light lambs from different fat classes in the EU carcass classification system
}

\author{
C. Sañudo ${ }^{a, *}$, M. Alfonso ${ }^{a}$, A. Sánchez ${ }^{a}$, R. Delfa ${ }^{b}$, A. Teixeira ${ }^{c}$ \\ ${ }^{a}$ Department of Animal Production, University of Zaragoza, 50013 Zaragoza, Spain \\ ${ }^{\mathrm{b}}$ Agricultural Research Service, Government of Aragón, 50080 Zaragoza, Spain \\ ${ }^{c}$ Polytechnical Institute of Braganza, 5300 Braganza, Portugal
}

Received 5 November 1999; received in revised form 31 January 2000; accepted 13 February 2000

\begin{abstract}
Ninety commercial lamb carcasses were analysed according to the four different fat classes in the light lamb European classification system. Shoulder fat increased 3\%, muscle decreased $2 \%$ and bone decreased $1 \%$ for each class increase. No significant differences were found among fat classes regarding $\mathrm{pH}$, WHC, cooking losses, juiciness, myoglobin content, meat colour measured immediately after cutting $\left(L^{*}, a^{*}, b^{*}\right)$, odour intensity or flavour quality. Some differences were found in colour evolution through ageing. Shear force decreased and tenderness and flavour intensity increased with fat class but this effect was only significant in the leanest animals. (C) 2000 Elsevier Science Ltd. All rights reserved.
\end{abstract}

\section{Introduction}

The quantity and quality of fat are important to consumers (Sendim, Albiac, Delfa \& Lahoz, 1997), who are more and more interested in healthy products and usually prefer lean meat and carcasses. As a result, a primary objective in many countries is the reduction of fat in order to improve the efficiency of commercial lamb production and prevent the demise of the sheep industry (Beermann, Robinson \& Hogue, 1995).

On the other hand, a balance should be reached since fat is also positively associated with acceptability. One would expect that making lambs less fat (per unit of carcass weight) would noticeably alter palatability. In this regard, Jeremiah, Smith and Carpenter (1972) and Jeremiah (1998) found that percentages of unacceptable cuts in terms of palatability were higher in lean than in fat categories (within the Canadian grading system) which lends support to and substantiates a positive relationship between fatness and palatability. Similar findings were also obtained by Paul, Tortem and Spurlock (1964) and Smith, Dutson, Hostetler and Carpenter (1976). However, the contribution that fat makes to

* Corresponding author. Tel.: + 34-976-76-21-32; fax: + 34-976-7615-90.

E-mail address: csanudo@posta.unizar.es (C. Sañudo). palatability remains controversial and the role of fatness in lamb quality is not completely understood (Jeremiah, 1998). On the other hand, an excess of fat clearly makes lamb less acceptable to the market, although this decrease in acceptability is not justified in terms of palatability.

For these and other reasons, practically all carcass classification systems around the world include a fatness score as a criterion of quality and price (Agriculture Canada, 1978; EEC 2137/92 and 461/93 regulations; Malmfors, 1995; Moxham \& Brownlie, 1976; United States Department of Agriculture [USDA], 1960). Other characteristics such as age, sex, weight, carcass length, meat colour and especially the conformation score are also used, but they have less market significance and a lower influence on the price than fat.

In the EU there are two different schemes for lamb classification: one for carcasses above $13 \mathrm{~kg}$ and another for carcasses below this weight. The conformation score is not considered in the latter scheme since Mediterranean carcasses are systematically penalised due to their naturally poor morphology (long-legged breeds), besides having a low subcutaneous/internal fat ratio and light weight. Thus, only weight (three categories: $<7.0$ $\mathrm{kg}, 7.1-10.0 \mathrm{~kg}$ and $10.1-13.0 \mathrm{~kg}$ ), meat colour and fat class are included.

Several studies have found weak relationships between quality grades and palatability assessment. Jeremiah et 
al. (1972) concluded that several cuts from carcasses of different USDA quality grades did not differ significantly in palatability traits. Nevertheless, leg roasts from carcasses with $2.0 \mathrm{~mm}$ or less subcutaneous fat had less flavour and decreased overall satisfaction. Crouse, Ferrell, Field, Busboom and Miller (1982) also showed that carcass quality and yield grades were not correlated with flavour, as previously reported by Weller, Galgan and Jacobsen (1962) and Carpenter and King (1965). However, other studies demonstrate that lamb meat is more acceptable for higher fat grade carcasses (Paul et al., 1964; Smith et al., 1976). All these studies were carried out on heavy carcasses but this relationship has not been investigated for a light lamb grading system.

It also seems essential to know whether any classification system can relate real carcass value to some expected palatability or consumer acceptance. The main goal of this study was to determine if the fatness levels described by the European regulation for light lamb carcasses are a good discriminator of meat quality.

\section{Material and methods}

We analysed ninety lamb carcasses, mainly from the Rasa Aragonesa breed, a medium wool breed, typical of the Mediterranean area, rustic type, 50-60 kg ewe mature weight, with a population of approximately 2.5 million head in Aragón (a semi-arid region situated in North-eastern Spain).

Lambs were reared, as is traditional in Aragón, with their dams for a minimum of 40-50 days and after weaning they were fed a high energy concentrate and cereal straw ad libitum until slaughter. Lamb carcasses (both sexes) were selected in a commercial EU licensed abattoir. Average cold carcass weight was between 8.5 and 12.5 $\mathrm{kg}$, which is typical in the European Mediterranean area.

The carcasses were selected to include the four fat levels of the EU lamb classification system (Table 1). Each class was divided into three subgroups: $-1,1,+1$; $-2,2,+2 ;-3,3,+3 ;-4,4$ and +4 . Only lambs between +1 and 4 (both subgroups included) were found commercially and 10 animals were studied per subgroup. Shortly after slaughter, the carcasses were placed into $4^{\circ} \mathrm{C}$ low air speed chill rooms for $24 \mathrm{~h}$ (according to the normal working practice). The left shoulder was then excised and dissected to provide an index of overall carcass composition following the guidelines in Colomer-Rocher, Delfa and Sierra (1988) for standard jointing and dissection techniques of light carcasses. Muscle, bone, subcutaneous and intermuscular fat were removed and proportions were calculated to obtain $100 \%$ of shoulder composition.

The entire left loin was also obtained to assess meat quality. Representative sub-samples of the $m$. longissimus thoracis (between the 6th and 13th ribs) were analysed instrumentally for quality traits at $72 \mathrm{~h}$ post mortem.

The $\mathrm{pH}$ was measured using a penetrating glass electrode and the water holding capacity (WHC) with a modified Grau and Hamm technique (Sierra, 1973). Weight losses were calculated after cooking in a $75^{\circ} \mathrm{C}$ water bath for $15 \mathrm{~min}$. This cooked sample was used to determine shear force and toughness (at right angles to the direction of the fibres). One portion of muscle was divided in $10 \mathrm{~mm}^{2}$ (cross-section) blocks, $20 \mathrm{~mm}$ long, with the longitudinal axis parallel to the fibres. They were measured using a Warner-Bratzler device mounted on an Instron Universal testing machine (4301).

Haem pigment concentration was calculated using a physico-chemical method (Hornsey, 1956). Meat colour evolution, using the $L^{*}, a^{*}, b^{*}$ system was estimated with Minolta (CM-2002) equipment. Two slices of 25 $\mathrm{mm}$ thick were obtained from the loin at $72 \mathrm{~h}$ post mortem. We measured colour at moment 0 (immediately after cutting), $24 \mathrm{~h}$ blooming in the same slice and 5 days blooming in the other. After the first measure (0), samples were kept at $3^{\circ} \mathrm{C}$ and packed in a plastic tray wrapped with oxygen permeable PVC film.

$M$. longissimus lumborum was used for sensory analysis. After $72 \mathrm{~h}$ ageing, the vacuum packed samples were blast frozen and kept at $-18^{\circ} \mathrm{C}$ until taste panel evaluation. The day of the panel session, samples were thawed under running tap water. Loins, at an initial temperature of $18-20^{\circ} \mathrm{C}$, were grilled until the internal temperature reached $70^{\circ} \mathrm{C}$. Hot samples were evaluated by a 10 member trained taste panel using a non-structured (1-100) scale. Panel members were asked to score odour intensity, tenderness, juiciness, flavour intensity, flavour quality and overall satisfaction. The left end of the lines $(=1)$ were labelled "no odour", "extremely tough", "extremely dry", "no aroma", "very disagreeable aroma" and "dislike extremely" and the right end (=100) were labelled "very strong odour", "extremely tender", "extremely juicy", "very strong aroma", "extremely agreeable aroma" and "like extremely". Three samples of three different fat classes were randomly assessed on the same plate. The number of judgements obtained was $100,300,300$ and 200 for the low (1), slight (2), average (3) and high (4) fat classes respectively.

Data were analysed using the GLM procedures of the Statistical Analysis System (SAS, 1987). Fat class differences were tested for significance at the 0.05 probability level (LSD).

\section{Results and discussion}

\subsection{Shoulder composition}

As expected, fat class discriminated tissue composition quite well, especially for subcutaneous and total fat 
Table 1

Number of animals used in this study by class and the EU carcass classification system for light lambs

\begin{tabular}{|c|c|c|c|c|c|c|c|c|c|}
\hline \multirow{2}{*}{$\frac{\text { Fat class }}{\text { Subgroup }}$} & \multirow{2}{*}{$\begin{array}{l}\text { 1-Low } \\
+1\end{array}$} & \multicolumn{3}{|c|}{ 2-Slight } & \multicolumn{3}{|c|}{ 3-Average } & \multicolumn{2}{|c|}{ 4-High } \\
\hline & & -2 & 2 & +2 & -3 & 3 & +3 & -4 & 4 \\
\hline Number of animals & 10 & 10 & 10 & 10 & 10 & 10 & 10 & 10 & 10 \\
\hline General fatness & None up to low fat cover & \multicolumn{3}{|c|}{$\begin{array}{l}\text { Slight fat cover, flesh } \\
\text { visible almost everywhere }\end{array}$} & \multicolumn{3}{|c|}{$\begin{array}{l}\text { Flesh, with exception of } \\
\text { hindquarter and shoulder, } \\
\text { almost everywhere covered } \\
\text { with fat. Slight deposits of } \\
\text { fat in the thoracic cavity }\end{array}$} & \multicolumn{2}{|c|}{$\begin{array}{l}\text { Flesh covered with fat, } \\
\text { but still partly visible on } \\
\text { the hindquarter and shoulder. } \\
\text { Some distinctive fat deposits } \\
\text { in the thoracic cavity }\end{array}$} \\
\hline External fatness & Traces or no visible fat & \multicolumn{3}{|c|}{$\begin{array}{l}\text { A slight layer of fat } \\
\text { covers part of the carcass } \\
\text { but may be less evident on } \\
\text { the limbs }\end{array}$} & \multicolumn{3}{|c|}{$\begin{array}{l}\text { A light layer of fat covering } \\
\text { most or all of the carcass. } \\
\text { Slightly thicker fat in the } \\
\text { tail base }\end{array}$} & \multicolumn{2}{|c|}{$\begin{array}{l}\text { A thick layer of fat covering } \\
\text { all of the carcass but may } \\
\text { be thinner on limbs and } \\
\text { thicker on the shoulders }\end{array}$} \\
\hline $\begin{array}{l}\text { Internal thoracic } \\
\text { fatness }\end{array}$ & $\begin{array}{l}\text { Traces or no fat visible } \\
\text { between ribs }\end{array}$ & \multicolumn{3}{|c|}{$\begin{array}{l}\text { Muscle clearly visible } \\
\text { between ribs }\end{array}$} & \multicolumn{3}{|c|}{$\begin{array}{l}\text { Muscle still visible between } \\
\text { ribs }\end{array}$} & $\begin{array}{l}\text { Mus } \\
\text { infil } \\
\text { may }\end{array}$ & $\begin{array}{l}\text { ribs may be } \\
\text { t. Fat deposits } \\
\text { the ribs }\end{array}$ \\
\hline
\end{tabular}

(shoulder dissection results are shown in Table 2). Subcutaneous shoulder fat increased $2 \%$ and total fat $3 \%$ for each increase in fat class. The differences in fatness could have been greater at both extreme classes, since the leanest $(-1$ and 1$)$ and fattest $(+4)$ were not included in our experiment. Variations in fat percentage between each class involved a 2 points decrease in muscle and 1 point in bone proportions, in agreement with the idea that bone is the least variable tissue in the carcass (Moxham \& Brownlie, 1976). In this context, it is important to emphasise that carcass grading could predict carcass composition in light lambs.

The shoulder composition results generally agree with previous findings in the same breed: 18.1 and 19.0\% shoulder fat with 3.1 and 3.4 of fatness score respectively in Delfa (1992) and Sañudo et al. (1998). The average value obtained by Osorio, Sierra, Sañudo, Maria and Osorio (1995), on carcasses of the same weight, but different ages, breeds and productions systems, was also similar to our average result.

Table 2

Shoulder composition (\%) and fat class in the EU carcass classification system for light lambs ${ }^{\mathrm{a}}$

\begin{tabular}{lllllll}
\hline Fat Class & 1-Low & 2-Slight & 3-Average & 4-High & s.e.d. & $F$ \\
\hline$n$ & 10 & 30 & 30 & 20 & & \\
Muscle & $66.3 \mathrm{a}$ & $64.6 \mathrm{a}, \mathrm{b}$ & $61.9 \mathrm{~b}, \mathrm{c}$ & $60.1 \mathrm{c}$ & 0.273 & $10.38^{* *}$ \\
Bone & $21.0 \mathrm{a}$ & $19.6 \mathrm{a}, \mathrm{b}$ & $18.9 \mathrm{~b}, \mathrm{c}$ & $17.8 \mathrm{c}$ & 0.160 & $5.04^{* *}$ \\
Subcutaneous fat & $3.2 \mathrm{a}$ & $5.8 \mathrm{~b}$ & $7.2 \mathrm{c}$ & $9.6 \mathrm{~d}$ & 0.190 & $15.4^{* *}$ \\
Intermuscular fat & $9.5 \mathrm{a}$ & $10.1 \mathrm{a}, \mathrm{b}$ & $11.9 \mathrm{~b}, \mathrm{c}$ & $12.4 \mathrm{c}$ & 0.109 & $7.11^{* *}$ \\
Total fat & $12.7 \mathrm{a}$ & $15.9 \mathrm{~b}$ & $19.1 \mathrm{c}$ & $22.0 \mathrm{~d}$ & 0.324 & $15.97^{*}$ \\
\hline
\end{tabular}

a Values in rows with different letters are significantly different; $*(P<0.05)$; ** $(P<0.01)$.

\subsection{Instrumental meat quality}

Fat classes did not differ significantly in $\mathrm{pH}$, WHC or cooking losses (Table 3 ). $\mathrm{pH}$ values were practically the same in all classes, suggesting that animals with different fatness had the same stress susceptibility and muscle glycogen content. These results agree with Kadim, Purchas, Davies, Rae and Barton (1993) who found no pH differences in lambs selected from high or low backfat lines, and Dransfield, Nute, Hogg and Walters, (1990) who found similar $\mathrm{pH}$ in lambs from different breeds and sex (and subsequently different fatness levels). Dubeski, Aalhus, Jones, Robelson and Dyck (1997) also found negligible $\mathrm{pH}$ differences at 6 days in heifers with significant fat differences.

The highest cooking losses $(\%)$ were in the lowest and highest fatness scored carcasses $(P>0.05)$. In general, meat cooking losses are positively associated with fatness (Babiker, Elkhuder \& Shafie, 1972; Kemp, Shelley, Ely \& Moody, 1990). But, fat could also act as protective layer to avoid evaporative losses, which would then be greater in leaner meat (Tichenor, 1969). This lack of protective fat in leaner carcasses could also favour losses by facilitating extra alteration in the protein structure during chilling and cooking.

Overall, it is possible that quite large differences in fatness are necessary to notice differences in lamb cooking losses. Kemp et al. (1972) found differences in animals with $10.2-28.5 \%$ trimmed fat. But, when fatness differences are small (as in our case), the relationship between fat and losses is insignificant (Bosman, Webb, Carey, Van Aardt \& Silvis, 1994; Dransfield, 1990; Fahmy, Boucher, Poste, Grégoire, Butler \& Comeau, 1992; Kadim, et al. 1993; Sañudo, Santolaria, Maria, Osorio \& Sierra, 1996). 
Table 3

Meat quality and fat class in the EU carcass classification system for light lambs ${ }^{\mathrm{a}}$

\begin{tabular}{|c|c|c|c|c|c|c|}
\hline Fat Class & 1-Low & 2-Slight & 3-Average & 4-High & s.e.d. & $F$ \\
\hline$n$ & 10 & 30 & 30 & 20 & & \\
\hline $\mathrm{pH}$ & 5.54 & 5.52 & 5.56 & 5.55 & 0.007 & NS \\
\hline Cooking losses $(\%)$ & 13.1 & 11.5 & 11.3 & 12.1 & 0.405 & NS \\
\hline WHC (\%) & 18.5 & 11.5 & 20.7 & 22.8 & 0.673 & NS \\
\hline Shear force $(\mathrm{kg})$ & $7.11 \mathrm{a}$ & $6.17 \mathrm{ab}$ & $5.36 \mathrm{~b}$ & $5.16 \mathrm{~b}$ & 0.180 & $* *$ \\
\hline Toughness $\left(\mathrm{kg} / \mathrm{cm}^{2}\right)$ & $2.05 \mathrm{a}$ & $1.96 \mathrm{ab}$ & $1.65 \mathrm{~b}$ & $1.59 \mathrm{~b}$ & 0.059 & $*$ \\
\hline $\mathrm{Mb}(\mathrm{mg} / \mathrm{g})$ & 2.15 & 2.45 & 2.51 & 2.37 & 0.051 & NS \\
\hline$L^{*} 0 \mathrm{~h}$ & 37.8 & 38.0 & 39.0 & 39.0 & 0.305 & NS \\
\hline$a^{*} 0 \mathrm{~h}$ & 13.0 & 13.3 & 13.8 & 13.9 & 0.152 & NS \\
\hline$b^{*} 0 \mathrm{~h}$ & 6.3 & 5.6 & 6.0 & 6.4 & 0.204 & NS \\
\hline$L^{*} 24 \mathrm{~h}$ & 41.2 & 41.1 & 41.6 & 41.3 & 0.270 & NS \\
\hline $\mathrm{a} * 24 \mathrm{~h}$ & $15.0 \mathrm{~b}$ & $15.3 \mathrm{ab}$ & $16.1 \mathrm{ab}$ & $16.7 \mathrm{a}$ & 0.183 & $*$ \\
\hline$b^{*} 24 \mathrm{~h}$ & $12.3 \mathrm{a}$ & $9.7 \mathrm{~b}$ & $11.2 \mathrm{ab}$ & $12.2 \mathrm{a}$ & 0.213 & $* *$ \\
\hline$L^{*} 5$ days & 35.9 & 37.5 & 36.8 & 38.1 & 0.358 & NS \\
\hline$a^{*} 5$ days & $16.0 \mathrm{a}$ & $14.1 \mathrm{~b}$ & $15.4 \mathrm{ab}$ & $15.9 \mathrm{a}$ & 0.198 & $* *$ \\
\hline$b^{*} 5$ days & $11.2 \mathrm{a}$ & $9.0 \mathrm{~b}$ & $9.5 \mathrm{ab}$ & $9.9 \mathrm{ab}$ & 0.226 & $*$ \\
\hline
\end{tabular}

a Values in rows with different letters are significantly different: * $(P<0.05) ; * *(P<0.01)$.

Shear force and toughness differences between fat classes were significant $(P<0.05)$ and tended to decrease with fatness. Greater amounts of fat (or high energy diets) are associated with lower shear force values in ruminant meat (Jeremiah et al., 1972; Smith et al., 1976; Babiker et al., 1990; Devine, Grafhuis, Muir \& Chrystall, 1993). However, some studies in fatter animals have shown that marbling is not closely related to instrumental measurements of tenderness (Woodhams, Kirton \& Jury, 1965), especially in animals with similar growth rates (Dubeski et al., 1997). Light carcasses with generally low subcutaneous fat thickness would have much less marbling than in many other published studies. These carcasses would also tend to suffer a negative effect from the chilling rate while fatter carcasses would be noticeably protected (Kadim et al., 1993; Sañudo et al., 1996). Fat possibly has more of an indirect effect than a causative one on meat tenderness.

There were no significant differences $(P>0.05)$ (Table $3)$ in pigment content, demonstrating that myoglobin concentration is probably less related to fatness at similar age-maturity (Dransfield et al., 1990; Sañudo, Campo, Sierra, Maria, Olleta \& Santolaria, 1997) than to age, even though the feeding conditions were identical (Field et al., 1990; Sañudo et al., 1996).

$L^{*} a^{*} b^{*}$ at moment 0 (immediately after cutting) were not significantly different between classes but some noticeable differences in colour evolution could be expected since $a^{*}$ and $b^{*}$ were significantly different at $24 \mathrm{~h}$ and 5 days blooming. Fat class 2 had the lowest $b^{*}$ values at both times and the lowest $a^{*}$ value at 5 days. $L^{*}$ was not significantly different between fat classes at any time, as found by Dubeski et al. (1997) in heifers, which demonstrates how little an influence fatness has on meat lightness.

\subsection{Sensory meat quality}

The quantity of intramuscular fat can affect organoleptic properties by replacing firm muscle fibres with soft fat. This makes meat more tender, lubrication is improved by the melted fat so that meat appears juicier, and fat traps and carries aroma compounds to improve taste (Enser, 1995). But fatty acid composition and the indirect effect of fat as a carcass protector should be also considered.

Tenderness, flavour intensity and overall acceptability were the only significantly different $(P<0.05)$ palatability meat characteristics between fat classes. No significant differences were found in odour intensity, juiciness and flavour quality (Table 4).

In agreement with trade opinion and our instrumental results, tenderness was higher in fatter carcasses. Similar results have been reported in beef (Jeremiah, 1996). The biggest difference in tenderness (more than 5.5 points) was between low and slight fat classes. The difference between the leanest and the next class was higher than between classes two (slight) and four (high) (which was lower than 4.5 points). As previously mentioned, these results could be related to problems during chilling in the leanest carcasses. Thus, it seems that a minimum of $16 \%$ shoulder fat should be required for this type of carcass to avoid cold problems in commercial abattoirs.

Tenderness, as all the other sensorial characteristics analysed, did not differ significantly between classes two, three and four. This supports the idea that, after a required minimum of fat, large differences in fatness are necessary to produce detectable changes in palatability. Enser (1995) indicated that marbling score and tenderness were significantly correlated in former studies of older animals with significant intramuscular fat content. 
Table 4

Sensory meat quality and fat class in the EU carcass classification system for light lambs ${ }^{\mathrm{a}}$

\begin{tabular}{|c|c|c|c|c|c|c|}
\hline Class fat & 1-Low & 2-Slight & 3-Average & 4-High & s.e.d. & $F$ \\
\hline$n$ & 100 & 300 & 300 & 200 & & \\
\hline Odour intensity & 45.2 & 49.4 & 47.5 & 49.2 & 0.572 & NS \\
\hline Tenderness & $45.9 \mathrm{a}$ & $50.54 \mathrm{a}, \mathrm{b}$ & $52.3 \mathrm{~b}$ & $54.9 \mathrm{~b}$ & 0.649 & $* *$ \\
\hline Juiciness & 41.2 & 44.1 & 43.9 & 42.2 & 0.631 & NS \\
\hline Flavour intensity & $46.8 \mathrm{a}$ & $52.00 \mathrm{a}, \mathrm{b}$ & $53.0 \mathrm{~b}$ & $54.4 \mathrm{~b}$ & 0.600 & $* *$ \\
\hline Flavour quality & 45.7 & 48.5 & 49.6 & 48.3 & 0.588 & NS \\
\hline Overall acceptability & $42.7 \mathrm{a}$ & $45.3 \mathrm{a}, \mathrm{b}$ & $47.0 \mathrm{~b}$ & $45.2 \mathrm{a}, \mathrm{b}$ & 0.549 & * \\
\hline
\end{tabular}

a Values in rows with different letters are significantly different: * $(P<0.05)$; ** $(P<0.01)$

The same was found by Kemp et al. (1972) when comparing wethers and rams with important differences in subcutaneous fat. Nevertheless, fat effects on palatability traits remain controversial in lamb (Jeremiah, 1998) and some authors did not find tenderness differences in carcasses with significant differences in fatness (Crouse et al., 1982; Dransfield et al. 1990; Jeremiah et al., 1972; Woodhams et al., 1965).

Juiciness differences were not significant, contrary to the general opinion that this taste trait increases with fatness (Jeremiah, 1996; Kemp et al. 1972; Woodhams et al., 1965). This could be explained by the juiciness interpretation made by our panel. It was evaluated after chewing and as juice released from the meat (Meilgaard, Curille \& Corr, 1991) and not as total moisture in the mouth, which fat increases by stimulating the salivary glands.

Flavour intensity increased with the fatness score, but many other authors have found no such relation (Crouse et al., 1982; Kemp et al., 1972) even when comparing animals with different carcass weights (Sañudo et al., 1996). However, Solomon, Kemp, Moody, Ely and Fox (1980) and Butler-Hogg et al. (1984) reported significant flavour differences between carcass weight classes, possibly because the heavier carcasses had a greater fat content.

As with tenderness, flavour intensity differed most between low and slight fat classes (by more than 5.0 points). The difference between slight and high classes was only 2.4 points. This is probably not only due to the quantity of fat, but to fat quality (Crouse et al., 1982), especially phospholipids, to which the panel would be especially sensitive, and phospholipid percentage changes with fatness level, being higher in leaner animals (Enser, 1995). On the other hand, Jeremiah et al. (1972) suggests that the deposition of more than $2.0 \mathrm{~mm}$ fat may increase flavour desirability, a tendency also reflected here.

Fat class 3 has the highest overall acceptability, which was different $(P<0.05)$ from the leanest carcasses. Similarly, Bosman et al. (1994) and Jeremiah (1998), also found a higher proportion of unacceptable meat from leaner carcasses. In beef, overall consumer acceptability is higher for an intermediate fat thickness $(1.00-1.19 \mathrm{~mm})$, but, as in our study, only significantly different from one of the leanest groups $(0.60-0.79 \mathrm{~mm}$ of subcutaneous fat thickness) (Jeremiah, 1996).

In conclusion, our results indicate that the European carcasses classification system for light lamb (considering fat classes) is a good discriminator of carcass composition. Although meat quality clearly improves with fatness, only the leanest animals are adversely affected. An optimum of quality and carcass market acceptability should be determined around an average fat class.

\section{Acknowledgements}

We are indebted to Fidel Lahoz and Juan Francisco Pardos for their technical assistance. We are also grateful to María del Mar Campo for her helpful discussions. This work was supported by the Instituto Nacional de Investigación y Tecnología Agraria y Alimentaria (INIA), as part of research SC94-078.

\section{References}

Agriculture Canada (1978). Lamb and mutton carcass grading regulations. Canada Gazette, 112, 4221-4226.

Babiker, S. A., El Khider, I. A., \& Shafie, S. A. (1990). Chemical composition and quality attributes of goat meat and lamb. Meat Science, 28, 273-277.

Beermann, D. H., Robinson, T. F., \& Hogue, D. E. (1995). Impact of composition manipulation on lean lamb production in the United States. Journal of Animal Science, 73, 2493-2502.

Bosman, M. J. C., Webb, E. C., Casey, N. H., M Van Aardt, A., \& Silvis, N. (1994). Die invloed van hoë-en medium-energiediëte in verpilde vorm op die eet-en vetkwaliteit asook gaarmaakverliese van lamsvleis van verskillende rasse. Tydskrif vir Dieetkundunde en Huishoudkunde, 22, 19-25.

Butler-Hogg, B. W., Francombe, M. A., \& Dransfield, E. (1984). Carcass and meat quality of ram and ewe lambs. Animal Production, 39, 107-114.

Carpenter, Z. L., \& King, G. T. (1965). Factors influencing quality of lamb carcasses. Journal of Animal Science, 24, 861-864.

Colomer-Rocher, F., Delfa, R., \& Sierra, I. (1988). Métodos normalizados para el estudio de los caracteres cuantitativos y cualitativos de las canales caprinas y ovinas producidas en el area Mediterránea, según los sistemas de producción. Cuadernos del INIA, 17, $19-41$. 
Crouse, J. D., Ferrell, C. L., Field, R. A., Busboom, J. R., \& Miller, G. J. (1982). The relationship of fatty acid composition and carcass characteristics to meat flavour in lamb. Journal of Food Quality, 5, 203-214.

Delfa, R. (1992). Clasificación de canales ovinas en la C.E.E.. El quinto cuarto. Ed. D.G.A. Dpto. Agricultura, Ganadería y Montes. Zaragoza $117 \mathrm{pp}$.

Devine, C. E., Grafhuis, A. E., Muir, P. D., \& Chrystall, B. B. (1993). The effect of growth rate and ultimate $\mathrm{pH}$ on meat quality of lambs. Meat Science, 35, 63-77.

Dransfield, E., Nute, G. R., Hogg, B. W., \& Walters, B. R. (1990). Carcass and eating quality of ram, castrated ram and ewe lambs. Animal Production, 50, 291-299.

Dubeski, P. L., Aalhus, J. L., Jones, S. D. M., Robetson, W. M., \& Dyck, R. S. (1997). Meat quality of heifers fattened to heavy weights to enhance marbling. Canadian Journal of Animal Science, 77, 635-643.

EEC lamb carcass classification system regulations, number: 2137/92 \& 461/93. Office for Official Publications of the European Communities. L- 2985, Luxembourg.

Enser, M. (1995). Meat lipids. In R. J. Hamilton, Developments in oils and fats (pp. 1-31). London: Blackie Academia \& Professional.

Fahmy, M. H., Boucher, J. M., Poste, L. M., Grégoire, R., Butler, G., \& Comeau, J. E. (1992). Feed efficiency, carcass characteristics, and sensory quality of lambs, with or without prolific ancestry, fed diets with different protein supplements. Journal of Animal Science, 70, 1365-1374.

Field, R. A., Maiorano, G., McCormick, R. J., Riley, M. L., Russsell, W. C., Williams, F. L., \& Crouse, J. D. (1990). Effect of plane of nutrition and age on carcass maturity of sheep. Journal of Animal Science, 68, 1616-1623.

Hornsey, H. C. (1956). The colour of cooked cured pork estimation of the nitric-oxide haem pigments. Journal of Science and Food Agriculture, 7, 534-540.

Jeremiah, L. E., Smith, G. C., \& Carpenter, Z. L. (1972). Ovine yield grades, II. Palatability attributes within various quality grades. Journal of Animal Science, 34, 196-202.

Jeremiah, L. E. (1996). The influence of subcutaneous fat thickness and marbling on beef. Palatability and consumer acceptability. Food Research International, 29, 513-520.

Jeremiah, L. E. (1998). Development of a quality classification system for lamb carcasses. Meat Science, 48, 211-223.

Kadim, I. T., Purchas, R. W., Davies, A. S., Rae, A. L., \& Barton, R. A. (1993). Meat quality and muscle fibre type characteristics of Southdown rams from high and low backfat selection lines. Meat Science, 33, 97-109.

Kemp, J. D., Shelley, J. M., Ely, D. G., \& Moody, W. G. (1972). Effects of castration and slaughter weight on fatness, cooking losses and palatability of lamb. Journal of Animal Science, 34, 60-562.

Malmfors, G. (1995). Lamb carcass grading in the Nordic countries. NJF Seminar: Production of sheep meat in accordance to market demands, Iceland, 256, 1-4.
Meilgaard, M., Civille, G. V., \& Carr, B. T. (1991). Sensory evaluation techniques. Boca Ratón FL: CRC Press.

Moxham, R. W., \& Brownlie, L. E. (1976). Sheep carcasses grading and classification in Australia. Wool Technology and Sheep Breeding, 23, 17-25.

Osorio, J. C., Sierra, I., Sañudo, C., Maria, G., \& Osorio, M. T. (1995). Estudio comparativo de la calidad de la canal en el tipo "ternasco" según procedencia. Agrociência, 3, 145-150.

Paul, P. C., Tortem, J., \& Spurlock, G. M. (1964). Eating quality of lamb. Overall comparisons and interrelationships. Food Technology, $18,1785-1788$.

Sañudo, C., Santolaria, M. P., Maria, G., Osorio, M. T., \& Sierra, I. (1996). Influence of carcass weight on instrumental and sensory lamb meat quality in intensive production systems. Meat Science, 42, 195-202.

Sañudo, C., Campo, M. M., Sierra, I., Maria, G., Olleta, J. L., \& Santolaria, P. (1997). Breed effect on carcass and meat quality of suckling lambs. Meat Science, 46, 357-365.

Sañudo, C., Sierra, I., Oleta, J. L., Martin, L., Campo, M. M., Santolaria, P., Wood, J. D., \& Nute, G. R. (1998). Influence of weaning on carcass quality, fatty acid composition and meat quality in intensive lamb production systems. Animal Science, 66, 175-187.

Sendim, A., Albiac, J., Delfa, R., \& Lahoz, F. (1997). Quality perception of light lamb carcasses. Eurocarne, 61, 17-26.

Sierra, I. (1973). Aportaciones al estudio del cruce Blanco Belga x Landrace: caracteres productivos, calidad de la canal y calidad de la carne. Revista del Instituto de Economia y Producciones Ganaderas del Ebro, 16, 43.

Smith, G. C., Dutson, T. R., Hostetler, R. L., \& Carpenter, Z. L. (1976). Fatness, rate of chilling and tenderness of lamb. Journal of Food Science, 41, 748-756.

Solomom, M. B., Kempt, J. D., Moody, W. G., Ely, D. G., \& Fox, J. D. (1980). Effect of breed and slaughter weight on physical, chemical and organoleptic of lamb carcasses. Journal of Animal Science, $51,1102-1107$.

Tichenor, D.A. (1969) Effects of rate of gain, slaughter weight and castration on selected chemical, histological and organoleptic characteristics of ovine muscle and adipose tissue. PhD Dissertation, University of Kentucky. USA.

Unitied States Department of Agriculture (1960). Official United States Standards for grades of lambs, yearlings and sheep. Agricultural Marketing Service. Service, 123.

Weller, M. W., Galgan, M. W., \& Jacobsen, M. (1962). Flavour and tenderness of lamb as influenced by age. Journal of Animal Science, 21, 927-929.

Woodhams, P. R., Kirton, A. H., \& Jury, K. E. (1965). Palatability characteristics of crossbred lambs as related to individual Southdown sires, slaughter age, and carcass fatness. New Zealand Journal of Agriculture Research, 9, 268-275. 